\title{
Evaluation of programs and interventions for physical activity promotion in primary health care in Pernambuco: construction and validation of instruments and fieldwork methods of the SUS+Ativo Project
}

\author{
Avaliação dos programas e intervenções de promoção da atividade física \\ na atenção básica à saúde de Pernambuco: construção, validação de \\ instrumentos e método de trabalho de campo do Projeto SUS+Ativo
}

\section{Mauro Virgílio Gomes de Barros', Emmanuelly Correia de Lemos', Juliana Rafaela Andrade da Silva', Caroline Ramos de Moura Silva', Silvio Aparecido Fonseca², Rafael Miranda Tassitano}

\begin{abstract}
The aim of this study was to describe methodological aspects of the Project SUS+Ativo - Evaluation of programs and interventions for physical activity promotion within the primary healthcare network in the state of Pernambuco. A methodological study, with descriptive analysis. The programs and interventions for physical activity promotion developed within the Primary Health Care system of the 184 municipalities in the state of Pernambuco, as well as the island of Fernando de Noronha, constituted this field of study. Data were collected from managers, professionals and users involved in these programs and interventions. For the subgroup of managers and professionals, a census was conducted, while for participants the sample was dimensioned by the size of the municipalities and number of programs and interventions on physical activity that were active at the time. The instruments presented the following dimensions: individual characteristics of respondent (socio economic profile and education); characteristics and management of the program/intervention being evaluated; technical competency of professionals; perception of the quality of the programs and/or interventions. An observation script was used, filled by the researchers, for assessment of the environment and ongoing activities. Results were presented according to the phases: $1^{\text {st }}$ ) construction of matrixes, $2^{\text {nd }}$ ) face and content validity; $3^{\text {rd }}$ ) clarity and applicability of the instruments and $4^{\text {th }}$ ) analysis of reproducibility for the instrument. Methodological resources used in this study may support the development of new research of evaluation of process, structure and results, as well as the planning of programs and interventions for physical activity promotion in the field of public health.
\end{abstract}

\section{Keywords}

Motor activity; Health Care; Epidemiology.

\section{Resumo}

Descrever os aspectos metodológicos do Projeto SUS+Ativo - Avaliação dos programas e intervenções para promoção da atividade física na rede de Atenção Básica à Saúde no estado de Pernambuco. Estudo de caráter metodológico, com abordagem descritiva. $O$ campo de estudo foi constituído pelos programas e intervenções para promoção da atividade física, desenvolvidos na Atenção Básica à Saúde, dos 184 municípios do estado de Pernambuco mais a Ilha de Fernando de Noronha. Os dados foram coletados com gestores, profissionais e usuários envolvidos nesses programas e intervenções. Para os subgrupos de gestores e profissionais, optou-se por realizar um censo, já para os usuários a amostra foi dimensionada pelo porte dos municípios e número de programas e intervenções de atividade física que estavam em funcionamento em cada município. Os instrumentos foram constituidos pelas seguintes dimensões: características dos entrevistados (perfil socioeconômico e de formação); características e gestão do programa/intervenção avaliada; competência técnica dos profissionais; percepção sobre a qualidade dos programas e/ou intervenções. Foi utilizado um roteiro de observação, preenchido pelos pesquisadores, para avaliação do ambiente e das atividades desenvolvidas. Os resultados estão apresentados de acordo com as etapas: $1^{a}$ ) construção de matrizes, $2^{a}$ ) validade de face e conteúdo; $3^{a}$ ) clareza e aplicabilidade dos instrumentos e $4^{a}$ ) análise da reprodutibilidade do instrumento. Os recursos metodológicos utilizados nesse Projeto poderão subsidiar o desenvolvimento de novas pesquisas de avaliação sobre processo, estrutura e resultados, bem como subsidiar o planejamento dos programas e intervenções de promoção da atividade física no campo da saúde pública.

\section{Palavras-chave}

Atenção à saúde; Epidemiologia; Atividade motora. 


\section{Introduction}

The benefits of regular physical activity practice and the state of health of the population $^{1-3}$ in general consolidated the recommendation and stimulated the promotion of physical activity in public health among many countries ${ }^{4}$. As a consequence, governmental entities have created strategies to incorporate the physical activity theme in public health policies ${ }^{5-7}$. In Brazil, public investments in the field of physical activity promotion have been potentiated after the release of the Global Strategy on Diet, Physical Activity and Health ${ }^{5}$ and the National Policy for Health Promotion (NPHP) ${ }^{8}$.

The NPHP listed physical activity practice as one of its priorities and allowed, through financial support, the creation of projects and programs for physical activity promotion in over 1500 Brazilian municipalities ${ }^{13}$. In the initial years of creation of such policy until 2010, around $70 \%$ of municipalities developing projects for health promotion focused on actions that included physical activity ${ }^{13}$. Besides, the advent of the Nuclei of Support to Family Health (NSFH), in 2008, and the Academia da Saude Program, in 2011, strengthened the incorporation of physical activity in the field of Public Health ${ }^{13-14}$.

In this sense, the current scenario of expansion and consolidation of interventions in physical activity promotion, expressed by programs and/or projects for promotion of physical activity in the community, has developed the interest of research institutions and governmental offices for the conduction of evaluation studies $^{9-11,16 .}$ However, even though they present important results, Hoehner et al ${ }^{12}$ indicate there are few studies of evaluation that have been disseminated, and many present limitations in the methodological approaches used, since the selection of instruments, as well as the disclosure of methodological procedures. Therefore, it is necessary to propagate studies presenting the validation of instruments and methodologies for fieldwork to be set as basis for academic consultation and professional use by programs and interventions in the promotion of physical activity.

In this perspective, the Research Group in Lifestyles and Health at the University of Pernambuco (GPES-UPE) elaborated, during the years of 2013 and 2014, the research project entitled "Evaluation of programs and interventions for physical activity promotion in primary health care in Pernambuco - Project SUS+Ativo". The SUS+Ativo project can support the development of research in evaluation of programs and interventions in physical activity in the context of public health in the different Brazilian states. Therefore, the aim of this study was to describe the methodological aspects of the SUS+Ativo project, specifically study design, construction and validation of measurement instruments and procedures for fieldwork.

\section{Methods}

\section{Type of study}

The present study, characterized as methodological, of descriptive approach, refers to the Project entitled SUS+Ativo. The SUS+Ativo project is cross-sectional, statewide, with descriptive and analytical components focusing in the evaluation of the different macro processes related to operationalization, professional skills and management of programs and interventions for physical activity promotion developed within the Primary Health Care System in Pernambuco.

In order to execute the project, between November of 2013 and February of 2014, the following phases were undertaken: (1) construction and validation of instruments and (2) organization and execution of fieldwork. A post-doctorate, one 
doctorate, two graduate students and two professionals composed the technical committee of the project, all with academic and/or professional experience in the theme. All phases are detailed as follows:

\section{Construction and validation of instruments}

Considering this a broad Project with different goals, four instruments were developed. This process is justified by two reasons: (a) distinct specificity to the experience of managers and professionals, user perception and the environment; (b) lack of validated instruments to achieve the aim of the project.

The four instruments were built in four phases: $1^{\text {st }}$ ) construction of matrices, $2^{\text {nd }}$ ) face and content validity; $3^{\text {rd }}$ ) clarity and applicability of instruments and $4^{\text {th }}$ ) analysis of psychometric properties or testing of reproducibility, the last two conducted through a pilot study.

In the first phase (construction of matrices), during the months of November and December 2013, three rounds of committee meetings were conducted to define, initially, which indicators should compose the matrix of the four instruments. On this phase, managers and professionals from different Secretaries and health departments in the State of Pernambuco and other municipalities were also consulted on the construction of the matrix. Additionally, journal articles, thesis, dissertations, institutional reports, manuals and legislations pertaining to the aim of the study were used to theorize the matrix indicators.

Furthermore, the committee organized fours matrices in figures composed by dimensions and indicators that were sent to 81 specialists experienced in the evaluation of health services or with research in physical activity and health, epidemiology, as well as Physical Education professionals with experience in Primary Health Care or with a title as multiprofessional residency in Health. All were invited to proceed critically to the matrices through electronic forms (Google Docs application), with answer options in a likert scale of four points referring to pertinence of indicators (not pertinent, a little pertinent, pertinent or very pertinent). Also, it was allowed reviewers to write a review on an indicator, dimension or the matrices. It is important to note that managers and respective teams in the Secretary of Health Vigilance of the Ministry of Health also analyzed the matrices.

On the second phase (face and content validity), during the months of December 2013 and January 2014, suggestions and information from reviewers were taken into account to the construction of instruments. Therefore, one instrument was created to each interest focus of the Project SUS+Ativo (manager, professional, user and environment), and submitted to appreciation of the internal project committee in three rounds. After this procedure was concluded, versions of the fours instruments were, once more, sent out to the same specialists invited for the reviews on matrices, independently from having collaborated or not during the first phase.

For this procedure, the specialists were asked to evaluate, with response options in a likert scale, how adequate writing/language of questions seemed to be (not clear, a little clear, clear, very clear), how adequate scales of answers were (not adequate, a little adequate, adequate, very adequate) and, also, a general evaluation of the degree of quality of each questionnaire, according to the following options: very bad, regular, good, very good. Additionally, all items allowed the specialist to review indicating critics, comments and/or suggestions.

After the evaluations returned, the internal committee discussed the considerations and elaborated a consolidated version of all instruments for testing in a pilot study, in order to test the clarity of questions and applicability of instruments $\left(3^{\text {rd }}\right.$ 
phase) and the psychometric properties ( $4^{\text {th }}$ phase). In January 2014 training was conducted for the team responsible for data collection, as well as the evaluation of time and mode of application of instruments, following orientations on the interviewer manual. This phase also aimed at standardizing methodological procedures, such as definition of contact process to municipalities, scheduling visitation, among others.

For the application of the pilot study metropolitan municipalities of Recife were chosen. In this phase, the contact with the goal population (users, professionals and managers) allowed for the data collection team to build a summary with interviewer reports, suggestions from participants, inconsistency analysis for questions and answers, with all observations to the fieldwork phase, from organizing materials, staff, transportation, how to approach participants, adequate practice in questions and answers of instruments, among others.

After the pilot testing phase with the considerations from the document cited above, the final version was created, being the first instrument, directed at users of programs and/or interventions, developed to be applied as a face-to-face interview, guided by a structured questionnaire. The second instrument, directed at health professionals responsible for guiding sessions of physical activity or who collaborated some how to physical activity education in health activities, developed a structured self-guided questionnaire. A similar procedure was adopted for the construction of the third instrument, directed at managers for programs and/ or interventions, with three additional questions to be answered as an interview. At last, for environment measures, an instrument was constructed as an observation guide, to be filled by members of the research team.

To test semantic clarity of questions and applicability ( $3^{\text {rd }}$ phase) and instrument reproducibility ( $4^{\text {th }}$ phase), the questionnaire was applied and reapplied with a one-week difference with users $(n=40)$ and professionals $(n=20)$. For managers we opted for not doing the re-rest due to the way and strategies for application. The interview was face to face and had a mean duration of 60 minutes and it was allowed and encouraged a dialog about the instrument.

\section{Fieldwork methods}

Considering the territorial and logistic broadness of the project, the fieldwork operationalization was conducted from a consortium of four Higher education institutions: Federal University of Vale do São Francisco (UNIVASF), located in the backwoods, Faculdade ASCES, located in the Agreste, Rural Federal University of Pernambuco (UFRPE) and University of Pernambuco (UPE), located in the metropolitan region of Recife, being the project lead by researchers allotted in the last institution and under the responsibility of the members of the Lifestyles and Health Research Group (GPES - http://www.gpesupe.org/).

The steps of the fieldwork were: (a) training staff for data collection and (b) communication process and scheduling visitation in electable municipalities. The training for data collection staff that was definitive was conducted during the months of January (team UPE and UFRPE) and February (team UNIVASF and ASCES) 2014, with a load of eight hours. In total, three teams were assembled to represent UPE, UFRPE, ASCES and UNIVASF. During training the interviewer manual and the four data collection instruments were presented and discussed, at its final version. Moreover, there were simulations of instrument application (with the participants in the training). At this moment, there was better development of collection technique and questions were asked based on the consolidated document for the observations during the pilot study. 
The internal committee of the project coordinated the official communication to the municipalities about the research. As a strategy, there was a partnership beyond the universities, incorporating in the process the State Secretary of Health of Pernambuco (SEH-PE). The SEH-PE elaborated and sent a letter to all Municipal Secretaries of Health, with information about the project, its aims, and asking for support to the fieldwork required by the study with team visitations to the referred municipalities.

After sending out the letter, a researcher was responsible to contact all the 184 municipalities in the State of Pernambuco and the Island of Fernando de Noronha by phone or e-mail. The contact was made to ABS coordinators, municipal health secretaries or coordinators of programs to verify if in the municipalities in fact there were ongoing programs and/or interventions for PA promotion connected to the Municipal Secretary of Health. When there was a positive confirmation of the existence of such programs and/or interventions, a data and time were scheduled for data collection in the municipality.

An intervention for promotion of physical activity was considered when it was institutionally recognized in the national perspective (Academia da Saude Program - PAS), State (Academia da Cidade Program - PACID and Mae Coruja Program - mother owl, in English) and Municipal (Academia da Cidade Program - PAC, or similar), while intervention was considered as systematic actions for promotion of physical activity developed by professionals in the Nucleus for Support to Family Health (NSFH) through PA practice or orientation for PA practice in the groups within the units and the social equipment in the community. It may or may not be conducted by Physical Education professionals.

The following step constituted the selection of subjects (users, professionals and managers). For managers and professionals, there were no selection criteria, while looking to collect data from all of the available subjects during municipality visitation. For dimensioning of the sample of users, it was considered the size of the municipality and the existence of program or intervention for promotion of PA, and from that information the municipality scenario was defined and the minimum number of interviews, as presented in Figure 1.

Exemplifying, a municipality A, with 22 thousand inhabitants, and that through telephone contact of the health manager affirmed to have ongoing PACID and NSFH with the development of physical activity promotion, it would be necessary to collect data from a minimum of 12 users.

The research project to which this study is a part of was approved by the Ethics Committee in Research with Human Beings of the University of Pernambuco CAAE: 13373313.5.0000.5207. The participation of subjects was voluntary and through a signed consents form.

\section{Results}

The results are presented according to the following phases: $1^{\text {st }}$ ) construction of matrices, $2^{\text {nd }}$ ) face and content validity; $3^{\text {rd }}$ ) clarity and applicability of instruments and $4^{\text {th }}$ ) analysis of instrument reproducibility.

\section{Construction of matrices}

Considering the analysis of reviewers for the matrices of all instruments, a mean answer rate was 22 reviews, with a total of 30 from the management instrument, 19 for professional, 18 for users and 21 for environment. Additionally, reviewers, 79 for management instrument, 42 emitted 198 suggestions, questions or commentaries for professionals, 28 for users and 49 for environment, the final result can be seen in Figure 2. 


\begin{tabular}{|c|c|c|c|c|c|c|c|c|c|}
\hline \multirow{2}{*}{\multicolumn{3}{|c|}{$\begin{array}{l}\text { Strategy for dimensioning of the number of } \\
\text { users }\end{array}$}} & \multicolumn{7}{|c|}{ Scenarios } \\
\hline & & & \multirow{2}{*}{$\frac{1}{\mathrm{YES}}$} & \multirow[t]{2}{*}{2} & \multirow[t]{2}{*}{3} & \multirow{2}{*}{$\begin{array}{c}4 \\
\text { YES }\end{array}$} & \multirow{2}{*}{$\frac{5}{\mathrm{YES}}$} & \multirow[t]{2}{*}{6} & \multirow{2}{*}{$\frac{7}{\text { YES }}$} \\
\hline Tyne of & Mãe coruja & Cantos & & & & & & & \\
\hline ongoing & NSFH & Nuclei & & YES & & YES & & YES & YES \\
\hline & PAC or similar & Poles & & & YES & & YES & YES & YES \\
\hline \multirow{20}{*}{$\begin{array}{l}\text { Size of } \\
\text { municipality }\end{array}$} & \multirow{5}{*}{$<20$ thousand } & Pregnant & 2 & 2 & 0 & 3 & 2 & 2 & 3 \\
\hline & & Adolescents & 0 & 2 & 2 & 2 & 2 & 3 & 3 \\
\hline & & Adults & 0 & 3 & 3 & 3 & 3 & 4 & 4 \\
\hline & & Older adults & 0 & 2 & 2 & 2 & 2 & 3 & 3 \\
\hline & & Total & 2 & 9 & 7 & 10 & 9 & 12 & 13 \\
\hline & \multirow{5}{*}{$\begin{array}{l}20-49,4 \\
\text { thousand }\end{array}$} & Pregnant & 2 & 2 & 0 & 3 & 2 & 2 & 3 \\
\hline & & Adolescents & 0 & 2 & 2 & 2 & 2 & 3 & 3 \\
\hline & & Adults & 0 & 3 & 3 & 3 & 3 & 4 & 4 \\
\hline & & Older adults & 0 & 2 & 2 & 2 & 2 & 3 & 3 \\
\hline & & Total & 2 & 9 & 7 & 10 & 9 & 12 & 13 \\
\hline & \multirow{5}{*}{$\begin{array}{l}50-99,9 \\
\text { thousand }\end{array}$} & Pregnant & 3 & 3 & 0 & 4 & 3 & 3 & 4 \\
\hline & & Adolescents & 0 & 3 & 3 & 3 & 3 & 4 & 4 \\
\hline & & Adults & 0 & 4 & 4 & 4 & 4 & 5 & 5 \\
\hline & & Older adults & 0 & 3 & 3 & 3 & 3 & 4 & 4 \\
\hline & & Total & 3 & 13 & 10 & 14 & 13 & 16 & 17 \\
\hline & \multirow{5}{*}{$\begin{array}{l}100 \text { thousand } \\
\text { or more }\end{array}$} & Pregnant & 4 & 4 & 0 & 5 & 4 & 4 & 5 \\
\hline & & Adolescents & 0 & 4 & 4 & 4 & 4 & 5 & 5 \\
\hline & & Adults & 0 & 5 & 5 & 5 & 5 & 6 & 6 \\
\hline & & Older adults & 0 & 4 & 4 & 4 & 4 & 5 & 5 \\
\hline & & Total & 4 & 17 & 13 & 18 & 17 & 20 & 21 \\
\hline
\end{tabular}

FIGURE 1 - Dimensioning of the number of users according to the existence of ongoing interventions for promotion of PA and size of municipalities.

\section{Face and content validity and clarity and applicability of the instruments}

In face and content validity a mean response rate was 8 reviews (researchers) and a mean total of 13 reviews (professionals, managers and users). In general lines, the reviewers indicated a good evaluation relating to pertinence, evaluation of the degree of adequate writing, language on questions and answers and general evaluation of the questionnaire. In addition, reviewers also sent specific comments (mean of 49) for adjustment in questions and answer categories.

After the round of analysis of the matrices, four versions of instruments were constructed (manager, professional, user and environment) denominated Questionnaire for Evaluation of Interventions for Physical Activity Promotion in Primary Health Care. The version of the instrument for managers was constituted by fours components, 12 dimension and 167 questions; the version for professionals was constituted by three components, 16 dimensions and 151 questions; the version for users with three components, 9 dimension and 94 questions; and, the environment version, one component, 41 dimensions and 74 questions.

\section{Testing of Reproducibility of instruments}

The reproducibility (test and re-test) of instruments in the professional and user versions was tested through the intraclass correlation for continuous variables, Kappa for nominal variables and Spearman (rho) for ordinal scale variables. Values of $\geq 0,4$ were considered satisfactory. 


\begin{tabular}{|c|c|c|c|c|}
\hline Matrix & Component & Dimension & $\begin{array}{l}\text { \# of questions } \\
1^{1 \text { st }} \text { version }\end{array}$ & $\begin{array}{l}\text { \# of questions } \\
2^{\text {nd }} \text { version }\end{array}$ \\
\hline \multirow{12}{*}{ Managers } & \multirow{4}{*}{$\begin{array}{l}\text { Characteristics of } \\
\text { the respondent }\end{array}$} & Demographics & 08 & 08 \\
\hline & & Initial education (under graduation) & 07 & 14 \\
\hline & & Professional experience & 10 & 11 \\
\hline & & Continued and permanent education & 06 & 14 \\
\hline & \multirow{2}{*}{$\begin{array}{l}\text { Characteristics of } \\
\text { the intervention }\end{array}$} & Identification & 20 & 29 \\
\hline & & Organization of activities & 13 & 4 \\
\hline & \multirow{3}{*}{$\begin{array}{l}\text { Intervention } \\
\text { management }\end{array}$} & Evaluation & 10 & 10 \\
\hline & & Planning & 19 & 23 \\
\hline & & Operation & 19 & 16 \\
\hline & \multirow{3}{*}{$\begin{array}{l}\text { Perception } \\
\text { related to the } \\
\text { environment }\end{array}$} & Environment potentiality & 14 & 20 \\
\hline & & Safety & 09 & 9 \\
\hline & & Environment conservation & 06 & 6 \\
\hline \multirow{10}{*}{ Professionals } & \multirow{4}{*}{$\begin{array}{l}\text { Characteristics of } \\
\text { the respondent }\end{array}$} & Demographics & 08 & 08 \\
\hline & & Initial education (under graduation) & 07 & 14 \\
\hline & & Professional experience & 10 & 24 \\
\hline & & Continued and permanent education & 06 & 12 \\
\hline & \multirow{3}{*}{$\begin{array}{l}\text { Analytics of } \\
\text { professional skills }\end{array}$} & Knowledge & 18 & 41 \\
\hline & & Abilities & 14 & 9 \\
\hline & & Attitudes & 11 & 7 \\
\hline & \multirow{3}{*}{$\begin{array}{l}\text { Perception } \\
\text { related to the } \\
\text { environment }\end{array}$} & Environment potentiality & 14 & 20 \\
\hline & & Safety & 09 & 9 \\
\hline & & Environment conservation & 06 & 6 \\
\hline \multirow{11}{*}{$\begin{array}{l}\text { Environment } \\
\text { Users }\end{array}$} & \multirow{4}{*}{$\begin{array}{l}\text { Characteristics of } \\
\text { the respondent }\end{array}$} & Demographics & 14 & 15 \\
\hline & & State of Health & 0 & 4 \\
\hline & & Participation & 07 & 30 \\
\hline & & Interest level & 07 & excluded \\
\hline & \multirow{4}{*}{$\begin{array}{l}\text { Perception related } \\
\text { to quality of } \\
\text { interventions }\end{array}$} & Participation in planning and evaluation & 04 & 2 \\
\hline & & Care provided by professionals & 04 & 7 \\
\hline & & $\begin{array}{l}\text { Schedule, place and diversification of } \\
\text { activities }\end{array}$ & 07 & 0 \\
\hline & & Adequacy & 0 & 4 \\
\hline & \multirow{3}{*}{$\begin{array}{l}\text { Perception } \\
\text { related to the } \\
\text { environment }\end{array}$} & Environment potentiality & 14 & 19 \\
\hline & & Safety & 09 & 9 \\
\hline & & Environment conservation & 06 & 6 \\
\hline \multirow{5}{*}{ Researcher } & \multirow{5}{*}{$\begin{array}{l}\text { Assessment of the } \\
\text { environment }\end{array}$} & Activities & 07 & 9 \\
\hline & & Infra-structure and equipment & 22 & 40 \\
\hline & & Accessibility & 05 & 7 \\
\hline & & Safety & 07 & 8 \\
\hline & & Environment conservation & 06 & 10 \\
\hline \multicolumn{3}{|l|}{ Total } & 363 & 484 \\
\hline
\end{tabular}

FIGURE 2 - Consolidation of analytical matrices.

The final instrument for professionals was composed by 151 questions divided in three components, according to the description on table 1 . The first component relates to characteristics of the participant and is composed by 58 questions divided into four dimensions. Values for reproducibility tests were always significant and presented a mean always of or above 0.72 (dimension of professional experience). Only 4 questions (6.7\%) were below 0.4 . 
The second component provides the analysis of competency of the professional, composed by 57 questions divided into three dimensions. Mean values for the reproducibility test varied between 0.51 (abilities dimension) to 0.62 (knowledge dimension). A total of eight questions (14\%) presented values inferior to 0.4 , similar to the level of significance.

The third component relates to the environment perception and is composed by 35 questions divided into three dimensions. Mean values for reproducibility vary between 0.54 (environment potentiality dimension) and 0.62 (environment perception). A total of six questions presented values below 0.4 (17\%), in which the environment potentiality dimension presented values of $25 \%$ while safety did not present any values below what was recommended for the test.

The final instrument for users was composed of 91 questions divided into three components, as described on table 2. The first component relates to characteristics of the participant and is composed by 44 questions divided into three dimensions (demographics, state of health and participation). The mean value for all dimensions was above 0.60 and above the $80 \%$ in what concerns percentage of satisfactory values $(>0.40)$ and of significance $(\mathrm{p}<0.05)$.

The second component reports the perception on the quality of interventions, and is composed by 13 questions divided into three dimensions (participation in planning and evaluation, care provided by professionals, and adequacy). Mean values for the reproducibility test varied between 0.49 (care provided) to 0.56 (adequacy). Expect for the dimension of care provided, all other reached 100\% for the above-cited items with values beyond 0.4 and of test significance.

The third component relates to the perception of the environment and is composed by 34 questions divided into three dimensions. The mean value of reproducibility varied between 0.43 (environment conservation) and 0.54 (environment potentiality).

TABLE 1 - Reproducibility analysis for the instrument - professional version.

\begin{tabular}{|c|c|c|c|c|c|c|c|}
\hline & & \multirow{2}{*}{ Dimensions } & \multirow{2}{*}{ Questions } & \multicolumn{2}{|c|}{ Test value* } & \multirow{2}{*}{$\begin{array}{c}\% \text { of satisfactory } \\
\text { values }\end{array}$} & \multirow{2}{*}{$\begin{array}{l}\% \text { of items with } \\
\text { significant values }\end{array}$} \\
\hline & & & & Mean & Amplitude & & \\
\hline \multirow{10}{*}{ 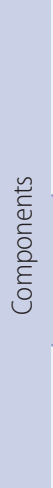 } & \multirow{4}{*}{$\begin{array}{l}\text { Characteristics } \\
\text { of the } \\
\text { respondent }\end{array}$} & Demographics & 8 & 0.94 & $0.81-1.00$ & 100 & 100 \\
\hline & & Initial education (under graduation) & 14 & 0.82 & $0.34-0.91$ & 92.9 & 100 \\
\hline & & Professional experience & 24 & 0.72 & $0.61-1.00$ & 95.8 & 100 \\
\hline & & Continued and permanent education & 12 & 0.76 & $0.45-0.73$ & 83.3 & 100 \\
\hline & \multirow{3}{*}{$\begin{array}{l}\text { Analytics of } \\
\text { professional } \\
\text { skills }\end{array}$} & Knowledge & 41 & 0.62 & $0.20-1.00$ & 85.3 & 87.8 \\
\hline & & Abilities & 9 & 0.51 & $0.26-0.77$ & 90.0 & 90.0 \\
\hline & & Attitudes & 7 & 0.61 & $0.20-0.79$ & 85.7 & 85.7 \\
\hline & \multirow{3}{*}{$\begin{array}{l}\text { Perception } \\
\text { related to the } \\
\text { environment }\end{array}$} & Environment potentiality & 20 & 0.54 & $0.20-0.84$ & 75.0 & 75.0 \\
\hline & & Safety & 9 & 0.61 & $0.34-0.92$ & 88.9 & 100 \\
\hline & & Environment conservation & 6 & 0.62 & $0.41-0.73$ & 100 & 100 \\
\hline
\end{tabular}

*Intraclass correlation test for continuous variables; Kappa for nominal variables and Spearman (Rho) for ordinal variables. Open questions were not included in reproducibility analysis.

\section{Fieldwork}

During the phase of data collection, the Superior School of Physical Education (ESEF) of the UPE was responsible for coordinating the research project and conduct data collection in seven of the twelve health regionals in the State of Pernambuco (municipalities from the I, II, III, V, VI, X and XII regionals). The team from ASCES was responsible for region IV and UNIVASF collected data in four regionals (VII, VIII, IX and XI). 
TABLE 2 - Reproducibility analysis for the instrument - user version.

\begin{tabular}{|c|c|c|c|c|c|c|c|}
\hline & & \multirow{2}{*}{ Dimensions } & \multirow{2}{*}{ Questions } & \multicolumn{2}{|c|}{ Test value* } & \multirow{2}{*}{$\begin{array}{c}\% \text { of satisfactory } \\
\text { values }\end{array}$} & \multirow{2}{*}{$\begin{array}{l}\% \text { of items with } \\
\text { significant values }\end{array}$} \\
\hline & & & & Mean & Amplitude & & \\
\hline \multirow{9}{*}{$\begin{array}{l}\frac{\tilde{c}}{d} \\
\frac{c}{0} \\
\stackrel{\varrho}{\varepsilon} \\
\text { है }\end{array}$} & \multirow{3}{*}{$\begin{array}{l}\text { Characteristics of } \\
\text { the respondent }\end{array}$} & Demographics & 15 & 0.69 & $0.24-1.00$ & 91.0 & 95.4 \\
\hline & & State of Health & 4 & 0.63 & $0.37-0.93$ & 83.3 & 100 \\
\hline & & Participation & 25 & 0.65 & $0.22-1.00$ & 80.0 & 88.0 \\
\hline & \multirow{3}{*}{$\begin{array}{l}\text { Perception } \\
\text { related to quality } \\
\text { of interventions }\end{array}$} & $\begin{array}{l}\text { Participation in planning and } \\
\text { evaluation }\end{array}$ & 2 & 0.55 & $0.42-0.67$ & 100 & 100 \\
\hline & & Care provided by professionals & 7 & 0.49 & $0.30-0.71$ & 71.4 & 71.4 \\
\hline & & Adequacy & 4 & 0.56 & $0.46-0.71$ & 100 & 100 \\
\hline & \multirow{3}{*}{$\begin{array}{l}\text { Perception } \\
\text { related to the } \\
\text { environment }\end{array}$} & Environment potentiality & 19 & 0.54 & $0.37-0.71$ & 89.4 & 89.4 \\
\hline & & Safety & 9 & 0.45 & $0.30-0.81$ & 77.8 & 88.9 \\
\hline & & Environment conservation & 6 & 0,43 & $0.31-0.52$ & 66.7 & 83.3 \\
\hline
\end{tabular}

*Intraclass correlation test for continuous variables; Kappa for nominal variables and Spearman (Rho) for ordinal variables. Open questions were not included in reproducibility analysis.

Each team, formed by four researchers, was responsible for visitation of one city per day but, depending on proximity of municipalities and different schedules of intervention, this number came up to two visits per day. The data collection team visitation went during the hours of programs and interventions. Usually this schedule varied between 5:00 a.m. and 8:00 p.m.

During visitation the collection teams were divided as follows: one researcher responsible for the environment instrument, also responsible for following managers and professionals interview at the end of applying the first instrument. The remaining researchers were responsible for interviewing users. Each interview with users lasted for about 30 minutes.

When arriving to places where interventions and/or programs were being held, researchers presented themselves to professionals who were aware and, when not aware, the research and its goals were also presented and following they presented themselves to users, who were invited to participate. The team of researchers remained in the location until all interviews had been concluded with users who accepted to participate. In some cases, it was necessary to go to different places, beyond where interventions were held, to guarantee the interviews with users, for example, their residences.

In case of professionals and managers working at both PACID and NSFH programs, they must respond to two questionnaires, each one taking into consideration the place and characteristics of that intervention. The same way only in reverse, when municipalities were contacted and there was confirmation of interventions for promotion of physical activity being developed at both the NSFH and the PACID pole, but, when arriving at the location it was identified that in fact the intervention was only in one if the programs, the professionals involved would only respond to one questionnaire.

According to the communication released before the teams went to the municipalities to collect data, the information obtained by telephone allowed to predict the amount of individuals to collect data from, in this case, organization until this moment (only the IV regional has not been collected), there was a forethought to collect from 124 managers, 348 professionals, 1047 users and 190 environments. However, that number was reached with in August 2015, with a total of 146 managers, 388 professionals, 978 users and 166 environments.

Through field diaries from the researchers, it was possible to identify facilitator and barrier aspects for conducting fieldwork, as described on Figure 3. 


\begin{tabular}{|c|c|c|}
\hline Items & Facilitators & Barriers \\
\hline Preliminary contact and scheduling & $\begin{array}{l}\text { Partnership with State Secretary of Health } \\
\text { Expressive participation of municipalities }\end{array}$ & $\begin{array}{l}\text { Constant change of managers in the municipalities } \\
\text { Outdated or inexistent contacts. } \\
\text { Lack of understanding the aims of the study by managers and } \\
\text { professionals (qualify versus supervise) }\end{array}$ \\
\hline Displacement/travel and lodging & $\begin{array}{l}\text { Knowledge of municipalities by the research } \\
\text { team }\end{array}$ & Team with few experienced people to drive long distances \\
\hline $\begin{array}{l}\text { Reception of the research team by } \\
\text { users in the municipalities }\end{array}$ & $\begin{array}{l}\text { Curiosity to know the study } \\
\text { Interest to improve spaces destined to } \\
\text { physical activity practice }\end{array}$ & Not being informed of the visit of the research team \\
\hline $\begin{array}{l}\text { Reception of the research team by } \\
\text { professionals in the municipalities }\end{array}$ & $\begin{array}{l}\text { Interest to improve quality of the work } \\
\text { offered to users }\end{array}$ & $\begin{array}{l}\text { Incompatible hours with the research team's visit } \\
\text { Activities performed only for the purpose of the research team's } \\
\text { visit }\end{array}$ \\
\hline $\begin{array}{l}\text { Reception of the research team by } \\
\text { managers in the municipalities }\end{array}$ & $\begin{array}{l}\text { Point out what has been done regarding } \\
\text { physical activity in the municipality }\end{array}$ & $\begin{array}{l}\text { Misunderstanding the aims of the visit from the research team } \\
\text { Develop programs, interventions, activities in general only for the } \\
\text { moment the research team's visit was undergoing }\end{array}$ \\
\hline Questionnaire application & Contemplated diverse dimensions & Length of professional version instrument \\
\hline Funding & $\begin{array}{l}\text { Funding from the Foundation for Support } \\
\text { to Science and Technology in the State of } \\
\text { Pernambuco (FACEPE), of the Professional } \\
\text { Development Coordination (CAPES) and the } \\
\text { CNPQ. }\end{array}$ & $\begin{array}{l}\text { Financing agencies not providing funds in the determined } \\
\text { deadline } \\
\text { Reduction and delay of financial support by the funding agencies }\end{array}$ \\
\hline
\end{tabular}

FIGURE 3 - Description of facilitators and barriers for the developing the study, identified by researchers.

\section{Discussion}

According to detailed methodological procedures and with the most rigor possible for this type of study, important contributions were observed to the process and the products derived from the construction of instruments for data collection.

Regarding the process, we may highlight the attention put into the literature review and meetings with the project team for construction of matrices and instruments. The expedition in the process of construction of matrices, as well as the contribution of managers and professionals of different educational backgrounds and locations in the country is another important point. We intended to reach for an expressive number of specialists $(n=81)$ and $17 \%$ for those invited returned with reviews, a relatively good response rate once all regions of Brazil were represented (validity) and over 200 reviews, suggestions and comments were received. We believe the use of a free app for reviews has contributed to the agility and responsiveness, beyond saving the expense on project budget.

In the process of constructing the matrices and the instruments, the form utilized allowed for triangulation of information derived from questions with open answers in a closed scale and, also, open questions. Even though all quantitative indicators were favorable by $63 \%$ of reviewers, the team members put an extra effort in the discussion, contemplation and adequacy of the suggestions present in the reviews.

As for derived products of the construction process of the instruments, it stands out the fact that quantitative metrics reveal acceptable indicators of writing/language of questions, adequate levels of response scales and positive perception of the quality of questionnaires.

The method for obtaining answers from professional and managers (self-report) allows the use of instruments by different teams of researchers once it brings out the possibility to interview users of programs at the same time. The diversity and amount of matrices, components, dimensions and indicators in the instrument allows its total or partial use. Furthermore, it allows the creation through isolated or combined answers for the creation of other metrics of answers, in the 
option of knowledge scores, levels of knowledge (example: perceived knowledge domain and objectively measure knowledge domain) of physical activities in different cycles of life.

On psychometric analysis, most dimensions presented a satisfactory index, however, questions related to perception of safety and quality of environment had great amplitude for the professional as well as the user version of the instrument, which can be attributed to a modified perception of reality, not previously perceived, and when asked (test) was awaken, stimulated reflection and on a second moment (retest) allowed them to have a more detailed and critical analysis about the processes involving the programs and/or interventions they participate in.

This aspect was identified in the field diaries, when researchers returned for the second round and users commented on the possibility of offering a different response than the one reported the previous week, because of such more critical analysis of the reality. Another dimension to highlight on the same sense was the dimension of knowledge, where the same reported having searched information on certain subjects that were questioned during the first interview. However, these inferior results represent the minority of questions, therefore, it was preferred to keep such questions due to the positive evaluation from specialists.

Therefore, the four products generated related to the four versions of the instruments (Manager, Professional, User and Environment), are useful to be used in the Brazilian context and, mainly, in the programs Academia da Saude, similar and interventions of physical activity promotion developed in the NSFH. Its use will allow to establish criteria of comparability for strengths and frailties of the referred programs and interventions.

\section{Acknowledgments}

We thank all those people who directly or indirectly contributed to this project, especially users, professionals and managers, GPES e funding agencies (CNPQ, FACEPE and CAPES).

\section{Authors' contributions}

All the authors contributed in the conception of the project or analysis and interpretation of the data, writing the manuscript or critically reviewing for all intellectual content, as well as the approval of the final version to be published.

\section{Funding sources}

CNPq, FACEPE, CAPES.

\section{References}

1. Miranda LS, Sattelmair J, Chaves P, Duncan GE, Siscovick DS, Stein PK, et al. Physical Activity and Heart Rate Variability in Older Adults: The Cardiovascular Health Study. Circulation. 2014;129:2100-10.

2. Farias, ES Gonçalves EM, Morcillo AM, Guerra-Júnior G, Amâncio OMS. Effects of programmed physical activity on body composition in post-pubertal schoolchildren. $J$ Pediatr (Rio J). 2015;91(2):122-9.

3. Branco JC, Jansen K, Teixeira S, Carrapatoso S, Spessato B, Carvalho J, et al. Physical benefits and reduction of depressive symptoms among the elderly: Results from the Portuguese "National Walking Program”. Ciênc Saúde Coletiva. 2015;20(3):789-95.

4. World Health Organization. Global status report on non-communicable diseases 2010. Geneva: World Health Organization; 2011. 
5. World Health Organization. Global Strategy on Diet, Physical Activity and Health. Geneva, Switzerland: World Health Organization; 2004.

6. Neira M, Onis M. The Spanish strategy for nutrition, physical activity and the prevention of .obesity. Br J Nutr. 2006;96:S8-11.

7. Pate RR. A National Physical Activity Plan for the United States. J Phys Act health. 2009; 6:S157-8.

8. Brasil. Ministério da Saúde. Secretaria de Vigilância em Saúde. Secretaria de Atenção à Saúde. National Policy in Health Promotion/Ministry of Health, Secretary of Surveillance, Secretary of Primary Health Care. - 3. ed. - Brasília: Ministério da Saúde, 2010.

9. Bejarano BM. Analysis of experiences in promotion of physical activity. Rev. Salud Pública. 2006;8:42-56.

10. Gomes MA, Duarte MFS. Effectiveness of an intervention in physical activity for adults in the health family strategy: program action and health Floripa - Brazil. Rev Bras Ativ Fís Saúde. 2008;13(1):44-56.

11. Hallal PC, Tenório MCM, Tassitano RM, Reis RS, Carvalho YM, Cruz DKA, et al. Evaluation of the program for physical activity promotion Academia da Cidade in Recife, Pernambuco, Brazil: perceptions of users and non-users. Cad. Saúde Pública. 2010;26(1): 70-8.

12. Hoehner CM, Soares J, Perez DP, Ribeiro IC, Joshu CE, Pratt M. Interventions in Physical Activity in Latin America: a systematic review. Am J Prev Med 2008;34(3):224-33.

13. Malta D, Silva MMA, Albuquerque GM, Amorim RCAR, Araújo GB, Silva TS, et al. National Policy for Health Promotion, description of implementation of the physical activity and movement axis, 2006 to 2014. Rev Bras Ativ Fis e Saúde. 2014;19(3):286-99.

14. Coutinho SS. Competence of the Physical Education professional in primary health care. 2011. 207 f. Dissertation (Doctorate in Public Health). Escola de Enfermagem de Ribeirão Preto/Universidade de São Paulo, São Paulo, 2011.

15. Scabar TG, Pelicioni AF, Pelicioni MCF. Performance of Physical Education Professionals in the Unified Health System (SUS): analysis of the National Policy for Health Promotion and Guidelines of the Nucleus for Support of Family Health-NSFH. J Health Sci Inst. 2012;30(4):411-8.

16. Amorim TC, Knuth AG, Cruz DKA, Malta DC, Reis RS, Hallal PC. Description of municipal programs for physical activity promotion funded by the Ministry of Health. Rev Bras Ativ Fis Saúde. 2013;18(1):63-74.

CORRESPONDING

AUTHOR

RAFAEL MIRANDA TASSITANO

rafael.tassitano@gmail.com
Dom Manoel de Medeiros, S/N, Dois

Irmãos/ Recife/ Pernambuco.

CEP:52171-900. (081) 33206475 .
RECEIVED $\quad 02 / 12 / 2015$

APPROVED $12 / 01 / 2016$ 